\title{
$\longrightarrow$ 交献紹介心
}

1. 応用力学・機械力学

2. 工業材料・材料学

3. 䁚定機・測定法

4. 繁 - 䓡力学

5. 然料. 燃焼

6. 蒸笳発生装置

7. 蒸気原勤機・復水器
8. 内矮機関
9. 航空機 - 航靠発動機
10. 自動車・自動車機関
11. 鉄道 - 鉄道車雨
12. 船舶 - 舶用機图
13. 流体力学・水力機㭜
14. 正縮機・送風機

20. 紡織

21. 化学機娍

22. 繁造・水産機俄

23. 土木機械・鉱山機线

24. 工場管理・経济

25. 工業澈育

26. 雑

\section{1. 応用力学およど機械力学}

$531.43+539.6(02)$

\section{[19]摩，擦 現 象}

[Frictional Phenomena,An"drew Germant, Chemical Pub. Co. Inc., Brooklyn, N.Y. 1950, pp. 497, \$12.00] 本整は The Detroit Edison Co. の研究所の主任(物 理学)研究貣で安る著者が 1941 1943 年の閏に 16 回 にわたってJ. Appl. Phys. に同じ題目で発表した一連 の論交の内容走骨子とし，諎家の听究業績を之りいれ つつ签籍にまとめたもので5部22章上りなる。各部の 主題呿上び主要内容性A.摩擦現象一般(物理学括よび

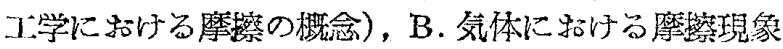

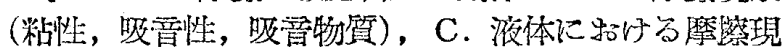

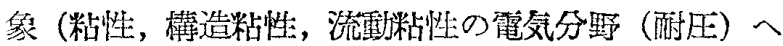

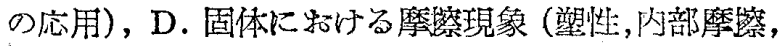
外部摩擦），E．間題和上ひ解答，のごとくで女って B D が本畫の圧倒的内容で女る。全巻を通ずる特徽 は多くの笑験事点を提示しつつ数学的取り报い棸力 避けてそれぞれの摩撚現象の本質に関する物建的説明 が与えられていることで岁るしか子本彗に盛られた 笑験データは著者影上び諸家によるきわめて近年の确

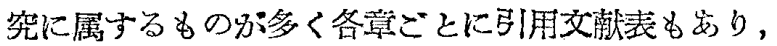
参考刺激となる点が多い。 [三井寿雄]

$539.3(02)$

\section{[20]工業材科おより゙構造物の非弾性挙動}

[The Inelastic Behavior of Engineering Materials and Structures, Alfred M. Freudenthal, John Wiley \& Sons, Inc., N.Y. 1950, pp. 587, \$8.00]

本書は著者(ロロンビヤ大学土木学郄授,イリノイス 大学講䝵) ダイリノイス大学蛒よびロロンビヤ大学に

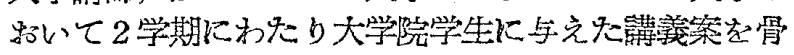

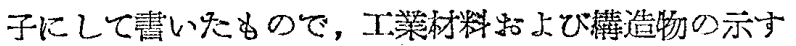

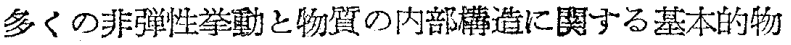

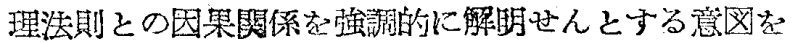

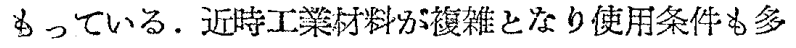
岐にわたる結果として材料の示す機栈的性行筫複綜し 多くの問題を提出しつつ岀る。このような材料の示す 性望を䍮なるマク口現象としてみるときに，そこに多 数の経験法則が生れるがそれらの間には統一がない。

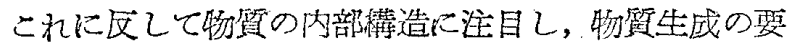

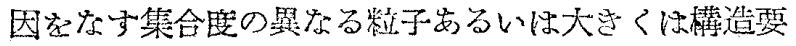

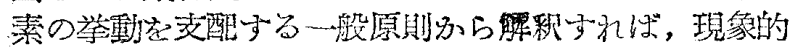

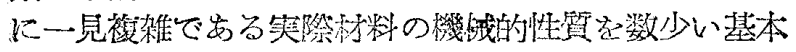

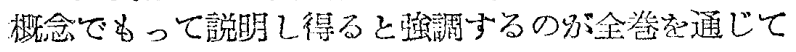

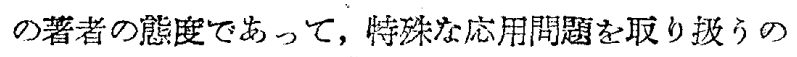
走主旨としない歹ら数式は基本法則起記述す名たけに

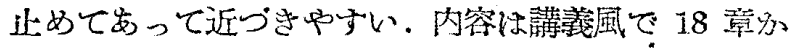
らなり，まず緒章に告いて材粼の機㭜的性質を学ぶ目 的, 物体, 力, 变形等の㯕会括上び定義, 研究法, 弹 性むよび非弹性举動等を入門的に論じ，つづくA部は

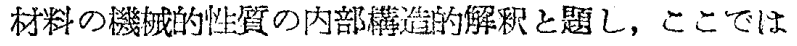

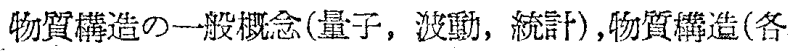

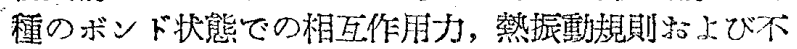

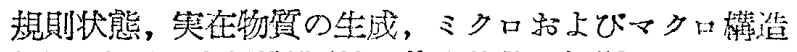

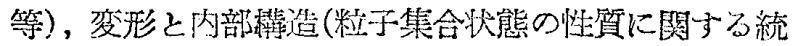

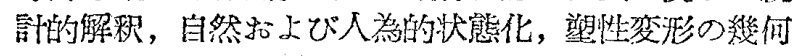

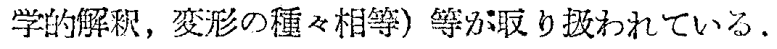

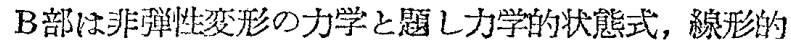

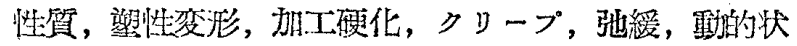
態での非弹性的性質等を主琵とし内答的に全巻の半分 在发てている。最後のC部は非巣性举動の力学の店用 で,まず普通の曲げ, ねじり，摩肉内筒，接蚛，プレ

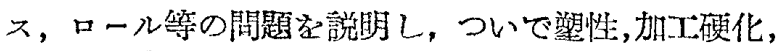

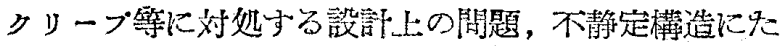

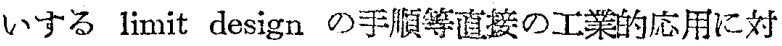
しても配慮が行われ，最挍に材粼試験の意議と結果の

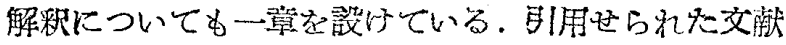

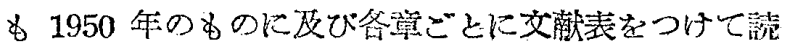
渚の模索に便ならしめている。【三贲寿雄]

$539.3 / .4(02)$

\section{[21]固体の流孔と破㙲の理論}

[Theory of Flow and Fracture of Solids, Vol. I, 2nd ed., A. Nadai, McGraw-Hill, H.Y. 1950, pp.

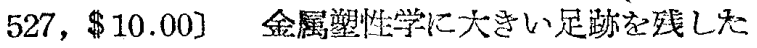
A. Nadai の労作で娄って 1927 年 Julius 基店名ら出 ‡ Der bildsame Zustand der Werkstoffe 炭るいは

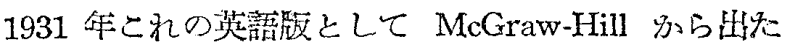
Plasticity 以来の著作で希る。第2 敌としたのは1931

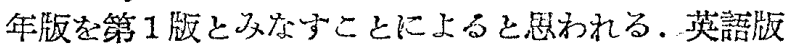

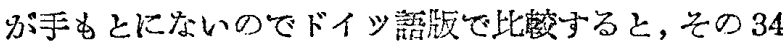

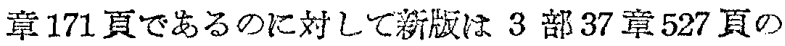

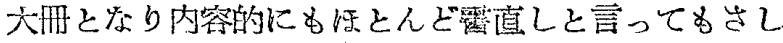
つかえなく，旧版以来の 20 年間に特ける斯学の発展

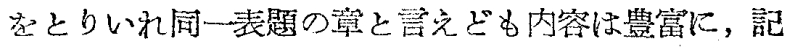

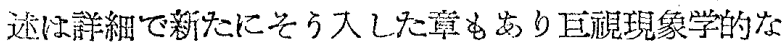
固体望性学の湆体系起形造っている。ます第 1 部小固

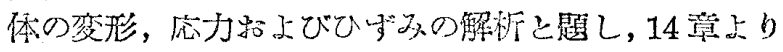


なり旧版では第 10 亲無限小ひずタすでに相当する部

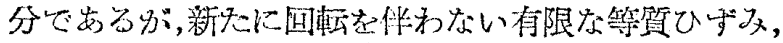

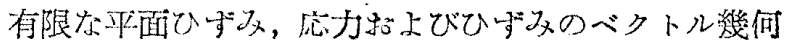
学の 3 章が迫加されている。第 2 部は 23 部までで固

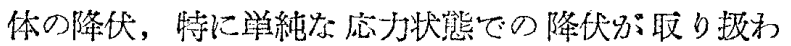

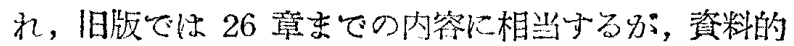
には著しく拡張せられ，恃に組合せ店力状態での降伏

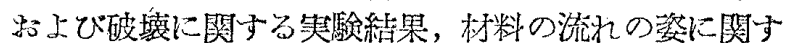

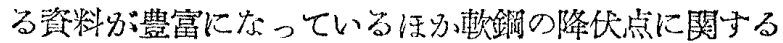

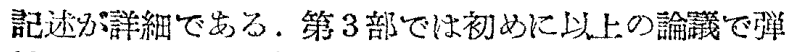

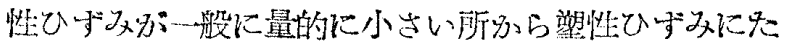

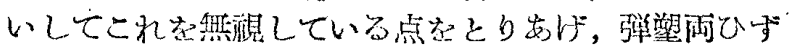

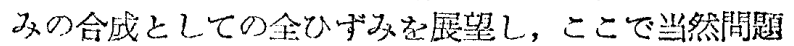
になる弾望闻域のポアンン比の関連に言更し，ついて

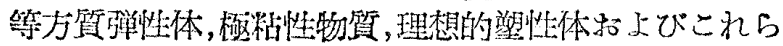

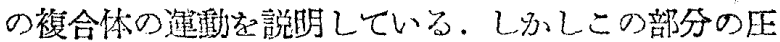

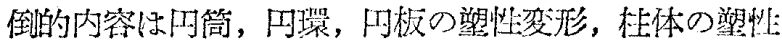

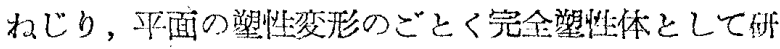

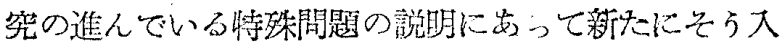

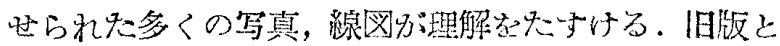

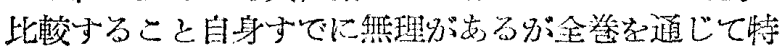
に感ぜられることは，一方に蛙いて内容が数理的にな ると同時に，一方では鋅富な写真，線图によって説明

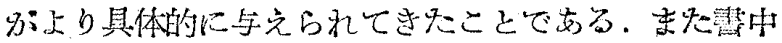
の随所に斯学の発展に大きい貢献を先䛭の消像を配し

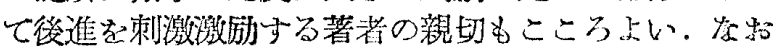

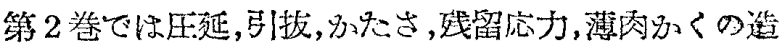

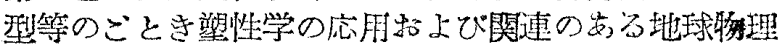

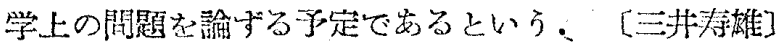

\section{5. 燃料,お}

621.694.2: 662.966 .4

\section{[22]火炬用の消煙装置として蒸汽 エゼクタを探用すること}

[R.B. Engdahl and W.S. Major, Technical Report No. 7, Bituminous Coal Research, Inc., 1947-8,

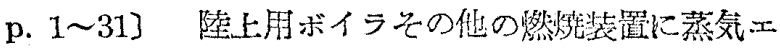
ゼクタ式消然装置を使うこと名行われている。相当是 い成績さ得をといら報告が多い，この装置の設䚺方法 標潐となる各部の寸法，棈造の詳細堂紹介している。

\section{〔横㸡 進〕}

\section{8. 內}

\section{燃}

621.436.13: $013+.05$

\section{[24] Scavenging of Two-Stroke Cycle Diesel Engine}

〔Paul. H. Schwertzer 漖，267貢，1949 年，New

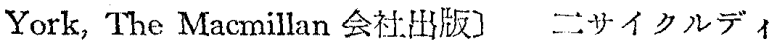

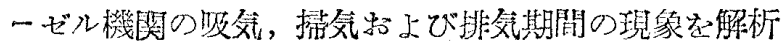

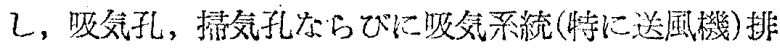
気系統の解析む上び者元の決定について述べており，

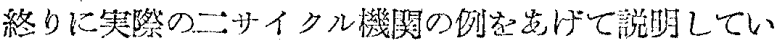

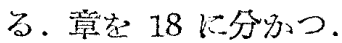

第1音はディーゼル機関の現況，ガソリン機関との 比較， ササイクルディーゼル穖関，これダ過給，お上 び高王道䌞，更にこれが一例としての Power Gas Process とその発澾の過程にられている。

第 2 龺は二サイクル機関の特做と題し，二シイクル

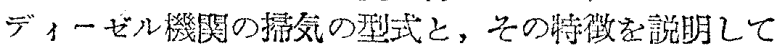
W\%.

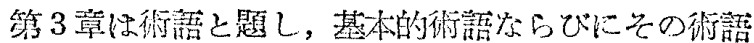

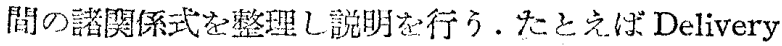
ratio, Trapping Eff., Scavenging Eff., Cylinder charge, Excess Air Factor, Perfect Scavenging, Per-

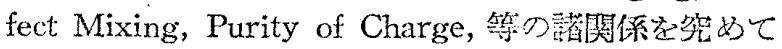
W.

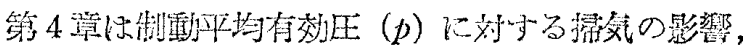

\section{よど，燃繞}

621.694.2: $662.966 .4(4)$

\section{[23]エゼク夕式消煙裝置の欧洲に おける発達}

[W. Gumz, Combustion, 1951-4; p. 39 48, 国

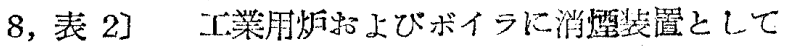

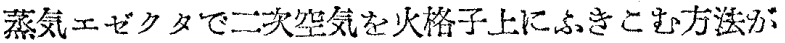

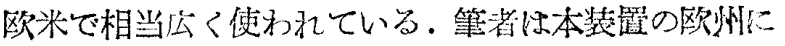

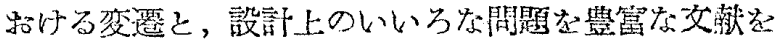
引用して説明する。【椣堸進】

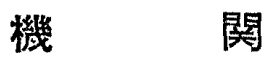

(p) と Relative cylinder charge $(c)$, Purity, 空爸過剩

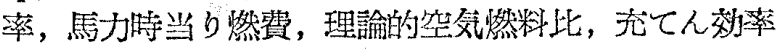

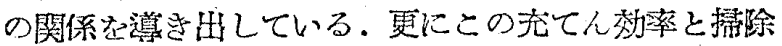
空氛の王力, 温度, 掃氛口形との関係起紹介している。

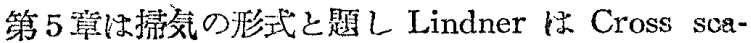

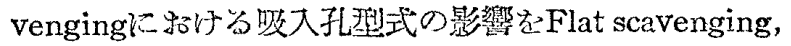
High-scavenging に分けて論じている。委た Cross, Loop, Uniflow scavenging の各型式について揟筑架

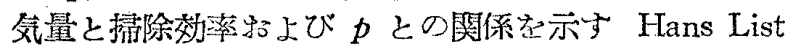
の笑験を詩細に紹介，批判している。

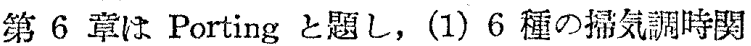

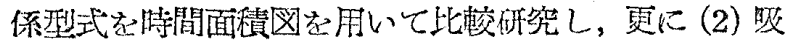

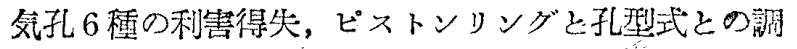
和作用(Ring Breakage)，(3) Bridge の寸法決定；ピ

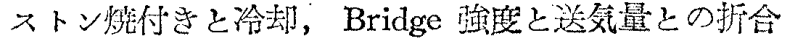
W, (4) 孔の功工洗-Rounding of Edge, Dressing of Port 等について迹べ最後に著者心 Portの珝想形式を して Gothic 型定推瘘している.

第 7 覃以吸氛孔之題す. Trapping Eff. $\left(\eta_{x r}\right)$ の基

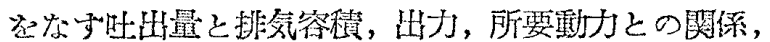

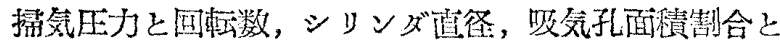

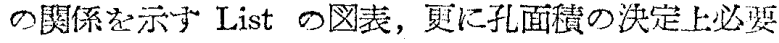

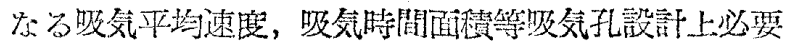
なる諧賴料について䛨述てている。

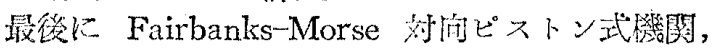

